\title{
Production of single cell oil from cane molasses by Rhodotorula kratochvilovae (syn, Rhodosporidium kratochvilovae) SY89 as a biodiesel feedstock
}

Tamene Milkessa Jiru ${ }^{1 *}$, Laurinda Steyn ${ }^{2}$, Carolina Pohl ${ }^{2}$ and Dawit Abate ${ }^{3}$

\begin{abstract}
Background: Single cell oil has long been considered an alternative to conventional oil sources. The oil produced can also be used as a feedstock for biodiesel production. Oleaginous yeasts have relatively high growth and lipid production rates, can utilize a wide variety of cheap agro-industrial wastes such as molasses, and can accumulate lipids above $20 \%$ of their biomass when they are grown in a bioreactor under conditions of controlled excess carbon and nitrogen limitation.

Results: In this study, Rhodotorula kratochvilovae (syn, Rhodosporidium kratochvilovae) SY89 was cultivated in a nitrogen-limited medium containing cane molasses as a carbon source. The study aims to provide not only information on the production of single cell oil using R. kratochvilovae SY89 on cane molasses as a biodiesel feedstock, but also to characterize the biodiesel obtained from the resultant lipids. After determination of the sugar content in cane molasses, R. kratochvilovae SY89 was grown on the optimized cane molasses for $168 \mathrm{~h}$. Under the optimized conditions, the yeast accumulated lipids up to $38.25 \pm 1.10 \%$ on a cellular dry biomass basis. This amount corresponds to a lipid yield of $4.82 \pm 0.27 \mathrm{~g} / \mathrm{L}$. The fatty acid profiles of the extracted yeast lipids were analyzed using gas chromatography, coupled with flame ionization detector. A significant amount of oleic acid (58.51 $\pm 0.76 \%)$, palmitic acid (15.70 $\pm 1.27 \%)$, linoleic acid (13.29 $\pm 1.18 \%)$ and low amount of other fatty acids were detected in the extracted yeast lipids. The lipids were used to prepare biodiesel and the yield was $85.30 \%$. The properties of this biodiesel were determined and found to be comparable to the specifications established by ASTM D6751 and EN14214 related to biodiesel quality.
\end{abstract}

Conclusions: Based on the results obtained, the biodiesel from R. kratochvilovae SY89 oil could be a competitive alternative to conventional diesel fuel.

Keywords: Cane molasses, Biodiesel, Oleaginous yeast, Single cell oil, Rhodotorula kratochvilovae (syn, Rhodosporidium kratochvilovae)

\section{Background}

Oleaginous microorganisms, including yeasts, which are capable of accumulating lipids, have long been considered an alternative to conventional oil sources. Oleaginous yeasts have high growth and lipid production rates, can utilize a variety of waste carbon sources

\footnotetext{
*Correspondence: tamene.milkessa@aau.edu.et

${ }^{1}$ Department of Biotechnology, University of Gondar, P.O.Box: 196,

Gondar, Ethiopia

Full list of author information is available at the end of the article
}

(including cheap agro-industrial residues such as molasses) and can accumulate lipids from 20 to $70 \%$ of their dry cell biomass when grown in a bioreactor under conditions of controlled carbon excess and nitrogen limitation $[1,2]$.

Biodiesel is a biodegradable, nontoxic, environmentally friendly and cleaner fuel alternative to petroleum-derived diesel fuel [3-6]. It has attracted much attention recently because it is made from renewable resources [7] and may reduce net carbon dioxide 
emissions by $78 \%$ on a life cycle basis [8] and hence contributes to the reduction in emissions to global warming [9].

Biodiesel is currently produced from plant oils and/ or animal fats by transesterification with short chain or low molecular weight alcohols such as methanol [6, 10-12]. However, producing biodiesel from vegetable oils or animal fats has many limitations. Firstly, it competes with the food market, since these oils and fats are also used for human consumption. Secondly, using oils, especially vegetable oils, as raw materials have high costs. Thirdly, more time and man power are needed for their production $[4,13]$. To compensate this cost, oleaginous microorganisms have to be grown on low cost feedstocks (agro-industrial wastes) and begin to replace the above fats and oil sources. These agro-industrial wastes include molasses, wheat bran, sugar cane bagasse, corn stover, wheat straw, saw mill and paper mill waste [14]. From the many substrates proposed for the economic conversion to lipids, molasses is considered as one of the best feedstocks for the cultivation of lipid producing microorganisms [15]. Molasses is a dark brown viscous liquid obtained as a by-product in the processing of cane or beet sugar. Molasses contains uncrystallized sugar and some sucrose. It is used in the production of bio-polymer [16], bio-surfactant [17], lactic acid [18], bio-ethanol [19-21] and biodiesel [15, 22-24].

Most of the oleaginous yeasts are basidiomycetes. Many basidiomycetous yeasts including Cryptococcus, Trichosporon and Rhodosporidium are now included in other existing or new genera [25]. Accordingly, Rhodosporidium has been transferred to Rhodotorula and the oleaginous yeast Rhodosporidium kratochvilovae is renamed as Rhodotorula kratochvilovae [25].

Although other substrates have been investigated as medium for lipid production by this yeast [26], this study aims to provide not only information on the production of single cell oil using the oleaginous yeast, $R$. kratochvilovae SY89 on cane molasses as a biodiesel feedstock, but also to characterize the biodiesel obtained from the resultant lipids.

\section{Methods}

\section{Yeast strain}

In this study, 200 samples were collected from soil, plant surfaces (leaves, flowers and fruits), traditional oil mill wastes, and dairy products (cheese, milk and yoghurt) in Ethiopia. Three hundred and forty yeast colonies were isolated from these samples. It was found that the yeast strain SY89, which was isolated from soil contained oil content of $39.33 \pm 0.57 \% \mathrm{w} / \mathrm{w}$. For identification purposes both conventional (morphological and physiological) and molecular (sequencing both ITS domains and D1/D2 domains of the large subunit) methods were undertaken by Jiru et al. [27]. Identification results led to assign strain SY89 as $R$. kratochvilovae.

\section{Inoculum preparation}

A pre-inoculum was prepared by taking a loopful of yeast cells from growing on slants of Yeast Malt (YM) extract agar (glucose $10 \mathrm{~g} / \mathrm{L}$, peptone $5 \mathrm{~g} / \mathrm{L}$, yeast extract $3 \mathrm{~g} / \mathrm{L}$, malt extract $3 \mathrm{~g} / \mathrm{L}$ and agar $20 \mathrm{~g} / \mathrm{L}$ ). This was inoculated into a sterilized nitrogen-limited medium containing [glucose $50 \mathrm{~g} / \mathrm{L},\left(\mathrm{NH}_{4}\right)_{2} \mathrm{SO}_{4} 0.31 \mathrm{~g} / \mathrm{L}$, yeast extract $0.50 \mathrm{~g} / \mathrm{L}, \mathrm{MgSO}_{4} \cdot 7 \mathrm{H}_{2} \mathrm{O} 1.5 \mathrm{~g} / \mathrm{L}, \mathrm{CaCl}_{2} \cdot 2 \mathrm{H}_{2} \mathrm{O} 0.1 \mathrm{~g} / \mathrm{L}$, $\mathrm{KH}_{2} \mathrm{PO}_{4} 1.0 \mathrm{~g} / \mathrm{L}, \mathrm{FeSO}_{4} \cdot 7 \mathrm{H}_{2} \mathrm{O} 0.035 \mathrm{~g} / \mathrm{L}, \mathrm{ZnSO}_{4} \cdot 7 \mathrm{H}_{2} \mathrm{O}$ $0.011 \mathrm{~g} / \mathrm{L}, \mathrm{MnSO}_{4} \cdot \mathrm{H}_{2} \mathrm{O} 0.007 \mathrm{~g} / \mathrm{L}, \mathrm{CoCl}_{2} \cdot 6 \mathrm{H}_{2} \mathrm{O} 0.002 \mathrm{~g} / \mathrm{L}$, $\mathrm{Na}_{2} \mathrm{MoO}_{4} \cdot 2 \mathrm{H}_{2} \mathrm{O} 0.0013 \mathrm{~g} / \mathrm{L}$ and $\left.\mathrm{CuSO}_{4} \cdot 5 \mathrm{H}_{2} \mathrm{O} 0.001 \mathrm{~g} / \mathrm{L}\right]$. The culture was allowed to grow for $24 \mathrm{~h}$ at $30^{\circ} \mathrm{C}, \mathrm{pH} 5.5$ at $200 \mathrm{rpm}$. From this culture, an inoculum of $10 \% \mathrm{v} / \mathrm{v}$ $\left(\sim 7.94 \times 10^{8}\right.$ cells $\left./ \mathrm{mL}\right)$ was added to the fermentation medium.

\section{Bioreactor cultivation using molasses as a substrate}

Molasses was used as a carbon source in the cultivation medium for this oleaginous yeast. The molasses was obtained from Wonji Sugar Factory, Wonji, Ethiopia. It was diluted to $50 \%(\mathrm{v} / \mathrm{v})$. The diluted molasses was then boiled, allowed to cool and sedimentation of insoluble materials occurred. The sediments were removed by decantation. The resulting molasses was centrifuged at $5000 \times g$ for $10 \mathrm{~min}$ for further removal of insoluble materials. The supernatant was separated from the pellet. The pellet was discarded and the supernatant was used for the cultivation purpose. Glucose, fructose and sucrose contents of the molasses were determined by HPLC (Waters Corp., Milford, MA, USA) using an Aminex HPX-87P column $(300 \times 7.8 \mathrm{~mm})$ at $85{ }^{\circ} \mathrm{C}$ with MilliQ water at a flow rate of $0.6 \mathrm{~mL} / \mathrm{min}$ as eluent. The injection volume was $10 \mu \mathrm{L}$. Peak identification of each sugar was based on the retention times (tR) of each sugar [sucrose ( $t R=17.45 \mathrm{~min})$, glucose $(t R=21.98 \mathrm{~min})$ and fructose $(\mathrm{t} R=25.96 \mathrm{~min})]$. Before the quantitative determination of sugars in the molasses, standard solutions of sucrose, glucose and fructose were prepared and used to prepare calibration curves for each sugar. The concentrations of the different sugars in the molasses were determined using these curves. The fermentation medium [Molasses $13.10 \% \mathrm{v} / \mathrm{v}(\sim 50 \mathrm{~g} / \mathrm{L}$ total sugar $),\left(\mathrm{NH}_{4}\right)_{2} \mathrm{SO}_{4} 0.31 \mathrm{~g} / \mathrm{L}$, yeast extract $0.50 \mathrm{~g} / \mathrm{L}, \mathrm{MgSO}_{4} \cdot 7 \mathrm{H}_{2} \mathrm{O} 1.5 \mathrm{~g} / \mathrm{L}, \mathrm{CaCl}_{2} \cdot 2 \mathrm{H}_{2} \mathrm{O}$ $0.1 \mathrm{~g} / \mathrm{L}, \quad \mathrm{KH}_{2} \mathrm{PO}_{4} 2.0 \mathrm{~g} / \mathrm{L}, \quad \mathrm{FeSO}_{4} \cdot 7 \mathrm{H}_{2} \mathrm{O} 0.035 \mathrm{~g} / \mathrm{L}$, $\mathrm{ZnSO}_{4} \cdot 7 \mathrm{H}_{2} \mathrm{O} \quad 0.011 \mathrm{~g} / \mathrm{L}, \quad \mathrm{MnSO}_{4} \cdot \mathrm{H}_{2} \mathrm{O} \quad 0.007 \mathrm{~g} / \mathrm{L}$, $\mathrm{CoCl}_{2} \cdot 6 \mathrm{H}_{2} \mathrm{O} 0.002 \mathrm{~g} / \mathrm{L}, \mathrm{Na}_{2} \mathrm{MoO}_{4} \cdot 2 \mathrm{H}_{2} \mathrm{O} 0.0013 \mathrm{~g} / \mathrm{L}$, and $\left.\mathrm{CuSO}_{4} \cdot 5 \mathrm{H}_{2} \mathrm{O} 0.001 \mathrm{~g} / \mathrm{L}\right]$ was autoclaved, inoculated with 
$10 \%(\mathrm{v} / \mathrm{v})$ of the liquid inoculum and cultivated in a FerMac 320, 0.8 L stirred-tank bioreactor. Fermentations were performed under the following optimized conditions [28]: work volume: $0.6 \mathrm{~L}$, stirring rate: $500 \mathrm{rpm}$, culture temperature, $30^{\circ} \mathrm{C}$, initial $\mathrm{pH}, 5.5$, aeration rate: $1.5 \mathrm{vvm}$ and culture time, $168 \mathrm{~h}$.

\section{Cell dry weight determination}

Yeast cells were harvested by centrifugation at $5000 \times g$ for $15 \mathrm{~min}$, washed twice with distilled water, frozen at $-80{ }^{\circ} \mathrm{C}$ and freeze dried overnight to constant weight. The dry biomass was determined gravimetrically [6].

\section{Determination of lipid content}

Lipid extraction was done following the protocol described by Folch et al. [29], with some modifications. Freeze dried biomass was ground with a pestle and mortar and $1 \mathrm{~g}$ of sample was extracted with $3.75 \mathrm{~mL}$ solvent mixture of chloroform and methanol (2:1) overnight. The solvent mixture was filtered (Whatman No 1 filter paper) into a clean separating funnel followed by the addition of $1.25 \mathrm{~mL}$ of the solvent mixture. The extract was washed with $0.75 \mathrm{~mL}$ of distilled water. The solvent/water mixture was left overnight to separate into two clear phases. The bottom phase was collected and the solvent mixture was evaporated under vacuum. Diethyl ether was used to transfer the extract into pre-weighed glass vials and the solvent evaporated. The dry lipids were weighed and lipid content calculated.

$$
\begin{aligned}
\text { Single cell oil content }(\%)= & \frac{\text { Single cell oil weight }(\mathrm{g} / \mathrm{L})}{\text { Cell dry weight }(\mathrm{g} / \mathrm{L})} \\
& \times 100
\end{aligned}
$$

\section{Analysis of fatty acids profiles using gas chromatography}

To determine the fatty acid composition of the lipids, the extracted lipids were dissolved in chloroform, transferred to GC vials and methylated with trimethylsulphonium hydroxide [30]. The vials were then sealed and vortexed for approximately $5 \mathrm{~s}$. Fatty acid methyl esters were subsequently analyzed on a Shimadzu GC-2010 gas chromatograph with a flame ionization detector. An injection volume of $0.5 \mu \mathrm{L}$ of sample was added into a SGE-BPX-70 column (length of $50 \mathrm{~m}$ and inner diameter $0.22 \mathrm{~mm}$ ). The injection port had a temperature of $250{ }^{\circ} \mathrm{C}$ and a split ratio of $1: 10$. The column temperature was $200{ }^{\circ} \mathrm{C}$. Hydrogen gas was used as a carrier gas at a flow rate of $40 \mathrm{~mL} / \mathrm{min}$. The total program time was 4.50 min per sample with a column flow rate of $1.37 \mathrm{~mL} / \mathrm{min}$. Peaks were identified by reference to authentic standards.

\section{Conversion of single cell oil into biodiesel}

After extraction of the microbial lipids, sulfuric acid catalyzed transesterification was performed in a $100 \mathrm{~mL}$ round bottom flask under the following conditions [31]: reaction time, $7 \mathrm{~h}$; agitation speed, $200 \mathrm{rpm}$; temperature, $55{ }^{\circ} \mathrm{C}$; oil and methanol molar ratio, $12: 1$ and catalyst, $0.25 \mathrm{~mL}$ of $80 \% \mathrm{H}_{2} \mathrm{SO}_{4}$. Petroleum ether was used to separate the biodiesel (upper) layer. The reaction mixture was cooled undisturbed and set aside for phase separation. The final product biodiesel was obtained after evaporating the ether solution. Biodiesel yield (wt\%) relative to the weight of the yeast lipid was calculated [31].

$$
\text { Biodiesel yield }(\%)=\frac{\text { Mass of biodiesel }}{\text { Theoretical mass }} \times 100
$$

\section{Characterization of biodiesel properties}

The different properties of biodiesel produced from the oil extracted from R. kratochviolovae SY89 was calculated directly from the FAME (fatty acid methyl ester) profiles using the online version of Biodiesel Analyzer Software (Biodiesel Analyzer@ Version, 2.2.,2016, http://www. brteam.ir/analysis/). The fuel properties of biodiesel analyzed include saponification value (SV), iodine value (IV), cetane number $(\mathrm{CN})$, cloud point $(\mathrm{CP})$, density $(\rho)$, kinematic viscosity $(\mathrm{v})$, oxidation stability $(\mathrm{OS})$, pour point (PP), cold filter plugging point (CFPP), long chain saturated factor (LCSF), high heating value (HHV), saturated fatty acid (SFA), monounsaturated fatty acid (MUFA), polyunsaturated fatty acid (PUFA), degree of unsaturation (DU), allylic position equivalent (APE) and bis-allylic position equivalent (BAPE).

\section{Statistical analysis}

All experiments were done in triplicate. One wayANOVA was performed to calculate significant differences in treatment means. SPSS version 20.0 software was used for interpretation of the data. Mean separations were performed by Tukey post hoc tests. A $p$ value $<0.05$ was considered significant.

\section{Results and discussion}

\section{Bioreactor cultivation using molasses as a substrate}

In this study, single cell oil production from cane molasses by $R$. kratochvilovae SY89 was developed for the first time. Prior to cultivation of $R$. kratochvilovae SY89, the concentrations of the three sugars present in cane molasses were determined using HPLC. The concentration of glucose, fructose and sucrose in molasses is presented in Table 1 . The estimated total sugar, calculated as the sum of the three sugars, was $38.28 \%$. 
Table 1 Composition of sugars in cane molasses

\begin{tabular}{ll}
\hline Sugars & $\begin{array}{l}\text { Composition } \\
\text { in cane molasses } \\
(\%)\end{array}$ \\
\hline Fructose & 21.05 \\
Glucose & 15.94 \\
Sucrose & 1.29 \\
Total & 38.28 \\
\hline
\end{tabular}

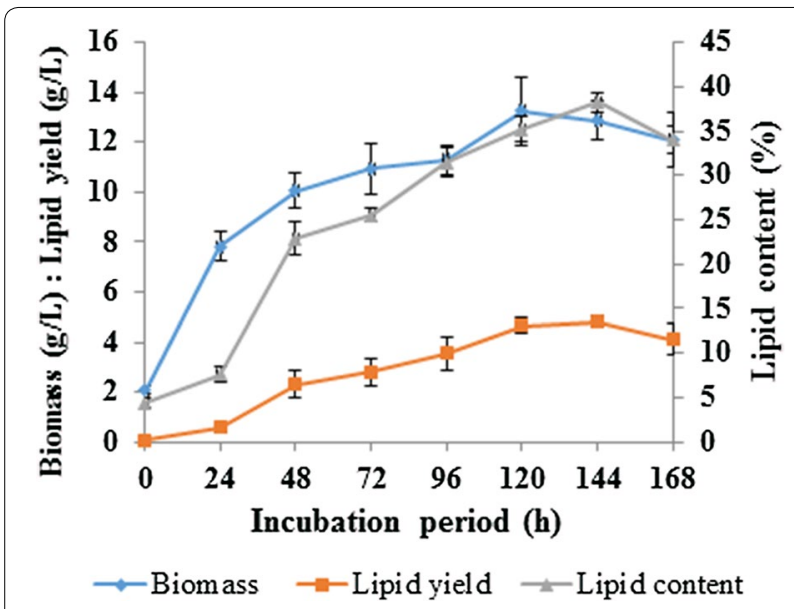

Fig. 1 Time course of biomass production, lipid yield and lipid content by R. kratochvilovae SY89 using molasses as a substrate in stirred tank bioreactor. Error bars in the figures represent standard deviation

After determination of sugar content in cane molasses, R. kratochvilovae SY89 was grown on the optimized cane molasses for $168 \mathrm{~h}$. Under these conditions, this yeast was able to accumulate lipids up to $38.25 \pm 1.10 \%$ on a cellular dry biomass basis. This result corresponds to a lipid yield of $4.82 \pm 0.27 \mathrm{~g} / \mathrm{L}$. This maximum value was obtained at $144 \mathrm{~h}$ of incubation. On the other hand, maximum biomass of $13.25 \pm 1.36 \mathrm{~g} / \mathrm{L}$ was achieved at $120 \mathrm{~h}$ of incubation (Fig. 1).

Previous studies also reported the use of molasses as a substrate for oleaginous yeasts such as $R$. glutinis [22], Candida lipolytica, C. tropicalis and Rhodotorula mucilaginosa [23], Geotrichum (syn, Trichosporon) fermentans [32], R. glutinis CCT 2182, Rhodotorula (syn, Rhodosporidium) toruloides CCT 0783, $R$. minuta CCT 1751 and Lipomyces starkeyi DSM 70296 [33] for the production of biomass and hence lipid yield.

\section{Fatty acid composition}

The quality of biodiesel depends upon the fatty acid composition of the oil feedstock. The data obtained in this study revealed that when cane molasses was used as a substrate, the yeast appeared to produce oleic acid as the largest lipid component $(58.51 \pm 0.76 \%)$, followed by palmitic acid $(15.70 \pm 1.27 \%)$, linoleic acid $(13.29 \pm 1.18 \%)$, stearic acid $(4.38 \pm 0.36 \%)$, linolenic acid $(2.76 \pm 0.97 \%)$ and palmitoleic acid $(0.59 \pm 0.17 \%)$. Trace amounts $(1.70 \pm 0.23 \%)$ of other fatty acids were also detected. The relative percentage of saturated and monounsaturated fatty acids of $R$. kratochvilovae SY89 adds up $79.18 \pm 2.56 \%$ which makes the lipids from this strain a suitable oil feedstock for biodiesel production [34]. Highly unsaturated fatty acids are easily oxidized during long term storage and have negative influence to the engine motor and are not recommended for biodiesel production [35].

Similar results on fatty acid profiles of other oleaginous yeasts grown on molasses were reported by other researchers $[33,36]$. Other researchers have also reported the fatty acid compositions of oleaginous yeasts that were grown on other wastes such as hydrolysate of cassava starch [37] and crude glycerol [38]. According to their reports, lipids from these yeasts also contained mainly oleic and palmitic and to a lesser extent linoleic and stearic acids. The fatty acid profiles of $R$. kratochvilovae SY89 were not only similar to fatty acid profiles of other oleaginous yeasts but are similar to the fatty acid profiles of different vegetable oils such as rapeseed, soybean, palm, and sunflower [39, 40].

\section{Production of biodiesel}

To produce microbial biodiesel, the extracted oil from R. kratochvilovae SY89 was transesterified using methanol and a yield of $85.30 \%$ was obtained. Dai et al. [3] also obtained a biodiesel yield of $81.70 \%$ from $R$. glutinis by growing the yeast on lignocellulosic wastes. From a previous study, biodiesel yields of $68 \%$ and $63 \%$ were obtained from heterotrophic growth of Chlorella protothecoides at molar ratio levels of $45: 1$ and 56:1, respectively [31]. From this one can see that the biodiesel yield obtained in this study is better than previous work.

\section{Characterization of biodiesel properties}

To evaluate the potential of biodiesel produced from $R$. kratochvilovae SY89 as a substitute for diesel fuel, the different physico-chemical properties were determined. As shown in Table 2, the results were compared with US biodiesel standard, ASTM D6751 [41] and EU biodiesel standard, EN14214 [42]. Iodine value (IV) for the produced yeast biodiesel, which is a measure of degree of unsaturation of a lipidic material, was $84.83 \mathrm{mg} \mathrm{I} / 100 \mathrm{~g}$ oil, which is below the maximum value of $120 \mathrm{mg} / 100 \mathrm{~g}$ oil standard of EN14214. The degree of unsaturation 
greatly influences fuel oxidation tendency. Cetane number $(\mathrm{CN})$ which is dimensionless descriptor and indicator of the combustion speed of diesel fuel is required for good engine performance [43]. It determines the combustion behavior of the biodiesel, i.e., ignition delay time, which is the time between the injection and ignition [44]. Higher $\mathrm{CN}$ helps to ensure good cold start properties and minimize the formation of white smoke. The $\mathrm{CN}$ recorded in this study was 55.60. This value is in agreement with the standards for biodiesel, which recommend a minimum CN of 47 (ASTM D6751) or 51 (EU biodiesel standard EN14214) [45]. The oxidation stability (OS) value of FAME for the present study was 9.94, which is an important feature related to the stability and performance of biodiesel. This shows the biodiesel produced from $R$. kratochvilovae SY89 oil is stable. The kinematic viscosity ( $\mathrm{v}$ ) of the biodiesel produced in this study was $3.66 \mathrm{~mm}^{2} / \mathrm{S}$ and therefore falls in the ranges set by both US biodiesel standard ASTM D6751 (1.6-9.0 $\left.\mathrm{mm}^{2} / \mathrm{S}\right)$ and EU biodiesel standard EN14214 $\left(3.5-5.0 \mathrm{~mm}^{2} / \mathrm{S}\right)$. The density $(\rho)$ recorded for this biodiesel was $0.83 \mathrm{~g} /$ $\mathrm{cm}^{3}$, which is approximated to the biodiesel standard of EN14214 $\left(0.86-0.9 \mathrm{~g} / \mathrm{cm}^{3}\right)$. Both kinematic viscosity (v) and density $(\rho)$ influence engine performance, combustion and exhaust emissions. A value of $-3.28^{\circ} \mathrm{C}$ for pour

Table 2 Selected physico-chemical properties of biodiesel produced from $R$. kratochvilovae SY89 grown on molasses compared to standard biodiesel specifications

\begin{tabular}{|c|c|c|c|}
\hline Biodiesel property & $\begin{array}{l}\text { Biodiesel } \\
\text { from SY89 }\end{array}$ & $\begin{array}{l}\text { US biodiesel } \\
\text { standard } \\
\text { ASTM D6751 }\end{array}$ & $\begin{array}{l}\text { EU biodiesel } \\
\text { standard } \\
\text { EN14214 }\end{array}$ \\
\hline SV (mg/g) & 192.30 & & \\
\hline IV mg I/100 g oil & 84.83 & NS & $<120$ \\
\hline $\mathrm{CN}$ & 55.60 & $>47$ & $>51$ \\
\hline $\mathrm{CP}\left({ }^{\circ} \mathrm{C}\right)$ & 3.27 & $3-15$ & -4 \\
\hline$\rho\left(\mathrm{g} / \mathrm{cm}^{3}\right)$ & 0.83 & NS & $0.86-0.9$ \\
\hline$u\left(\mathrm{~mm}^{2} / \mathrm{s}\right)$ & 3.66 & $1.6-9.0$ & $3.5-5.0$ \\
\hline OS (h) & 9.94 & $3 \min$ & $6 \min$ \\
\hline $\mathrm{PP}\left({ }^{\circ} \mathrm{C}\right)$ & -3.28 & -15 to 10 & NS \\
\hline CFPP $\left({ }^{\circ} \mathrm{C}\right)$ & -4.66 & $\begin{array}{l}\text { Summer max } \\
\text { 0; winter } \\
\text { max }<-15\end{array}$ & NS \\
\hline LCSF & 3.76 & NS & NS \\
\hline $\mathrm{HHV}\left({ }^{\circ} \mathrm{C}\right)$ & 37.63 & NS & NS \\
\hline SFA (\%) & 20.08 & NS & NS \\
\hline MUFA (\%) & 59.10 & NS & NS \\
\hline PUFA (\%) & 16.05 & NS & NS \\
\hline DU & 91.20 & NS & NS \\
\hline APE & 90.61 & NS & NS \\
\hline BAPE & 18.81 & NS & NS \\
\hline
\end{tabular}

NS non specified point (PP) was obtained in this study. This value also falls in the range set by US biodiesel standard ASTM D6751 $\left(-15\right.$ to $\left.10^{\circ} \mathrm{C}\right)$. Cloud point $(\mathrm{CP})$ of $3.27^{\circ} \mathrm{C}$ was obtained in this study. The value $3-15{ }^{\circ} \mathrm{C}$ is set by US biodiesel standard ASTM D6751. Saponification values (SV) are used to determine adulteration. A high SV of fats and oils is due to high proportion of shorter carbon chain lengths of the fatty acids and suggests that it has low levels of impurities [46]. A high SV of $192.30 \mathrm{mg} \mathrm{KOH/g}$ was recorded for $R$. kratochvilovae SY89 oil. The value recorded for long chain saturated factor is used to calculate the cold filter plugging point (CFPP), which is based on the amount of long chain saturated fatty acids (from $\mathrm{C} 16: 0)$ in the oil was $-4.66^{\circ} \mathrm{C}$. The CFPP value is related to the minimum temperature at which the biodiesel can generate clogging and problems in the motor [47]. The heating value of fatty acid esters increases with molecular chain length (with the number of carbon atoms) and decreases with their degree of unsaturation (the number of double bonds). The heating value for the biodiesel from $R$. kratochvilovae SY89 was $37.63{ }^{\circ} \mathrm{C}$. The biodiesel from this yeast oil could therefore be a competitive alternative to conventional diesel fuel. Other chemical and physical values were analyzed, including SFA (saturated fatty acid), MUFA (monounsaturated fatty acid), degree of unsaturation (DU), long chain saturated factor (LCSF), allylic position equivalent (APE) and bis-allylic position equivalent (BAPE) (summarized in Table 2). These characteristics are also important in determining the quality of a given biodiesel. Most of these properties are in agreement with the specifications established by ASTM D6751 and EN14214 related to biodiesel quality.

\section{Conclusions}

There are no reports in the literature concerning cultivation using $R$. kratochvilovae with molasses for the production of microbial oil. This study demonstrated that $R$. kratochvilovae SY89 is able to utilize molasses as a carbon source for the production of biomass and hence lipid yield. As such, this study expands the current knowledge in this regard. After pretreatment of molasses and optimization of its sugar concentration, sufficient dry biomass $(13.25 \pm 1.36 \mathrm{~g} / \mathrm{L})$, lipid yield $(4.82 \pm 0.27 \mathrm{~g} / \mathrm{L})$ and lipid content $(38.25 \pm 1.10 \%)$ were obtained in a bioreactor fermentation. Such single cell oil can be transesterified into biodiesel that conforms to international standards for such fuel. Production of microbial oil using cheap substrates such as molasses may be advantageous for countries like Ethiopia, since the cost of purchasing and transportation of petroleum oil can be reduced at least partially. 


\section{Authors' contributions}

TM performed the experiments as part of his doctoral work. All this work was carried out under the supervision of DA and CP. LS helped in the bioreactor experiment. DA and CP also helped in editing the manuscript. All authors read and approved the final manuscript.

\section{Author details}

${ }^{1}$ Department of Biotechnology, University of Gondar, P.O.Box: 196, Gondar, Ethiopia. ${ }^{2}$ Department of Microbial, Biochemical and Food Biotechnology, University of the Free State, P.O.Box: 339, Bloemfontein, South Africa. ${ }^{3}$ Microbial, Cellular and Molecular Biology Department, College of Natural Sciences, Addis Ababa University, P.O.Box: 1176, Addis Ababa, Ethiopia.

\section{Acknowledgements}

Authors would like to acknowledge Addis Ababa University and University of the Free State. Tamene is thankful to Ethiopian Ministry of Science and Technology for their financial support.

\section{Competing interests}

The authors declare that they have no competing interests.

\section{Availability of data and materials}

The sequence dataset generated for this isolate is available in the NCBI Short Read Archive repository (Accession Number KX525703).

\section{Funding}

This work was supported by the Ethiopian Ministry of Science and Technology. The ministry supported me in partial coverage of the costs for consumables and apparatuses.

\section{Publisher's Note}

Springer Nature remains neutral with regard to jurisdictional claims in published maps and institutional affiliations.

\section{Received: 21 August 2017 Accepted: 31 July 2018}

Published online: 10 August 2018

\section{References}

1. Hassan M, Blanc PJ, Granger LM, Pareilleux A, Goma G (1993) Lipid production by an unsaturated fatty acid auxotroph of the oleaginous yeast Apiotrichum curvatum grown in single stage continuous culture. Appl Microbiol Biotechnol 40:483-488

2. Meesters PAEP, Huijberts GNM, Eggink G (1996) High-cell-density cultivation of the lipid accumulating yeast Cryptococcus curvatus using glycerol as a carbon source. Appl Microbiol Biotechnol 45:575-579

3. Dai C, Tao J, Xie F, Dai Y, Zhao M (2007) Biodiesel generation from oleaginous yeast Rhodotorula glutinis with xylose assimilating capacity. Afr J Biotechnol 6:2130-2134

4. Kraisintu P, Yongmanitchai W, Limtong S (2010) Selection and optimization for lipid production of a newly isolated oleaginous yeast, Rhodosporidium toruloides DMKU3-TK16. Kasetsart J (Nat Sci) 44:436-445

5. Enshaeieh M, Abdoli A, Madani M, Bayat M (2015) Recycling of lignocellulosic waste materials to produce high-value products: single cell oil and xylitol. Int J Environ Sci Technol 12:837-846

6. Pan LX, Yang DF, Shao L, Li W, Chen WGG, Liang ZQ (2009) Isolation of the oleaginous yeasts from the soil and studies of their lipid producing capacities. Food Technol Biotechnol 47:215-220

7. Li Q, Du W, Liu D (2008) Perspectives of microbial oils for biodiesel production. Appl Microbiol Biotechnol 80:749-756

8. Tyson KS (2001) Biodiesel handling and use guidelines. http://www nrel.gov/docs/fy06osti/40555.pdf. Accessed 23 Sept 2015

9. Ahmad M, Khan MA, Zafar M, Sultana S (2013) Practical handbook on biodiesel production and properties. CRC Press, Florida

10. Alcantara R, Amores J, Canoira L, Fidalgo E, Franco MJ, Navarro A (2000) Catalytic production of biodiesel from soybean oil, used frying oil and tallow. Biomass Bioenergy 18:515-527
11. Vicente G, Martinez M, Aracil J (2004) Integrated biodiesel production: a comparison of different homogenous catalysts systems. Bioresour Technol 92:297-305

12. Liu GQ, Lin $Q L$, Jin XC, Wang XL, Zhao Y (2010) Screening and fermentation optimization of microbial lipid-producing molds from forest soils. Afr J Microbiol Res 4:1462-1468

13. Vicente G, Bautista L, Rodriguez R, Gutierrez FJ, Sadaba I, Ruiz-Vazquez RM, Torres-Martinez S, Garre V (2009) Biodiesel production from biomass of an oleaginous fungus. Biochem Eng J 48:22-27

14. Yousuf A (2012) Biodiesel from lignocellulosic biomass-prospects and challenges. Waste Manag 32:2061-2067

15. Sabry SA, Ghanem KM, Yusef HH (1990) Production of microbial lipids from beet molasses. J Islamic Acad Sci 3:310-313

16. Berwanger ALD, Scamparini ARP, Domingues NM, Vanzo LT, Treichel H, Padilha FF (2007) Biopolymer production synthesized by Sphingomonas capsulata, using industrial media. Cienc Agrotec 31:177-183

17. Nitschke M, Ferraz C, Pastore GM (2004) Selection of microorganisms for biosurfactant production using agro-industrial wastes. Braz J Microbiol 35:81-85

18. Coelho LF, De Lima CJB, Rodovalho CM, Bernardo MP, Contiero J (2011) Lactic acid production by new Lactobacillus plantarum LMISM6 grown in molasses: optimization of medium composition. Braz J Chem Eng 28:27-36

19. Periyasamy S, Venkatachalam S (2009) Production of bio-ethanol from sugar molasses using Saccharomyces cerevisiae. Mod Appl Sci 3:32-37

20. Fadel M, Keera AA, Mouafi FE, Kahil T (2013) High level ethanol from sugar cane molasses by a new thermotolerant Saccharomyces cerevisiae strain in industrial scale. Biotechnol Res Int. https://doi. org/10.1155/2013/253286

21. Arshad M, Ahmed S, Zia MA, Rajoka MI (2014) Kinetics and thermodynamics of ethanol production by Saccharomyces cerevisiae MLD10 using molasses. Appl Biochem Biotechnol 172:2455-2464

22. Almazan O, Klibansky M, Otero MA (1981) Microbial fat synthesis by Rhodotorula glutinis from blackstrap molasses in continuous culture. Biotechnol Lett 3:663-666

23. Karatay SE, Donmez G (2010) Improving lipid accumulation properties of the yeast cells for biodiesel production using molasses. Bioresour Technol 101:7988-7990

24. Gajdoš P, Nicaud JM, Rossigno T, Čertík M (2015) Single cell oil production on molasses by Yarrowia lipolytica strains overexpressing DGA2 in multicopy. Appl Microbiol Biotechnol 99:8065-8074

25. Wang QM, Yurkov AM, Göker M, Lumbsch HT, Leavitt SD, Groenewald M, Theelen B, Liu XZ, Boekhout T, Bai FY (2015) Phylogenetic classification of yeasts and related taxa within Pucciniomycotina. Stud Mycol 81:149-189

26. Patel A, Pravez M, Deeba F, Pruthi V, Singh RP, Pruthi PA (2014) Boosting accumulation of neutral lipids in Rhodosporidium kratochvilovae HIMPA1 grown on hemp (Cannabis sativa Linn) seed aqueous extract as feedstock for biodiesel production. Bioresour Technol 165:214-222

27. Jiru TM, Abate D, Kiggundu N, Pohl C, Groenewald M (2016) Oleaginous yeasts from Ethiopia. AMB Express 6:78

28. Jiru TM, Groenewald M, Pohl C, Steyn L, Kiggundu N, Abate D (2017) Optimization of cultivation conditions for biotechnological production of lipid by Rhodotorula kratochvilovae (syn, Rhodosporidium kratochvilovae) SY89 for biodiesel preparation. 3 Biotech 7:145

29. Folch J, Lees M, Sloane-Stanley GH (1957) A simple method for the isolation and purification of total lipids from animal tissues. J Biol Chem 226:497-509

30. Butte W (1983) Rapid method for the determination of fatty acid profiles from fats and oils using trimethylsulphonium hydroxide for transesterification. J Chromatogr A 261:142-145

31. Miao XL, Wu QY (2006) Biodiesel production from heterotrophic microalgae. Bioresour Technol 97:841-846

32. Zhu LY, Zong MH, Wu H (2008) Efficient lipid production with Trichosporon fermentans and its use for biodiesel preparation. Bioresour Technol 99:7881-7885

33. Vieira JPF, lenczak JL, Rossell CEV, Pradella JGC, Franco TT (2014) Microbial lipid production: screening with yeasts grown on Brazilian molasses. Biotechnol Lett 36:2433-2442 
34. Byreddy AR, Gupta A, Barrow CJ, Puri M (2015) Comparison of cell disruption methods for improving lipid extraction from Thraustochytrid strains. Mar Drugs 13:5111-5127

35. Metzger JO, Bornscheuer U (2006) Lipids as renewable resources: current state of chemical and biotechnological conversion and diversification. Appl Microbiol Biotechnol 71:13-22

36. Johnson VW, Singh M, Saini VS, Adhikari DK, Sista V, Yadav NK (1995) Utilization of molasses for the production of fat by an oleaginous yeast, Rhodotorula glutinis IIP-30. J Ind Microbiol 14:1-4

37. Li M, Liu GM, Chi Z, Chi ZM (2010) Single cell oil production from hydrolysate of cassava starch by marine-derived yeast Rhodotorula mucilaginosa TJY15a. Biomass Bioenergy 34:101-107

38. Tchakouteu SS, Kalantzi O, Gardeli C, Koutinas AA, Aggelis G, Papanikolaou S (2015) Lipid production by yeasts growing on biodiesel-derived crude glycerol: strain selection and impact of substrate concentration on the fermentation efficiency. J Appl Microbiol 118:911-927

39. Ma F, Hanna MA (1999) Biodiesel production: a review. Bioresour Technol 70:1-15

40. Christophe G, Kumar V, Nouaille R, Gaudet G, Fontanille P, Pandey A, Larroche C (2012) Recent developments in microbial oils production: a possible alternative to vegetable oils for biodiesel without competition with human food? Braz Arch Biol Technol 55:29-46

41. American Society for Testing and Materials (2002) Standard specification for biodiesel fuel (B100) Blend stock for distillate fuels. American Society for Testing and Materials (ASTM), D6751-02, West Conshohocken
42. ACEA (2009) Biodiesel Guidelines. European Automobile manufacturers' Association (ACEA), Brussels, Belgium, March 2009. http://www.acea.be/ images/uploads/files/20090423-B100-Guideline.pdf. Accessed 15 June 2015

43. Knothe G (2006) Analyzing biodiesel: standards and other methods. JAOCS 83:823-833

44. Islam MA, Magnusson M, Brown RJ, Ayoko GA, Nabi MN, Heimann K (2013) Microalgal species selection for biodiesel production based on fuel properties derived from fatty acid profiles. Energies 6:5676-5702

45. Minnesota Statutes: petroleum diesel fuel and biodiesel technical cold weather issues. Minnesota Department of Agriculture, Report to the Legislature, 2008, pp 1-16

46. Barku VYA, Nyarko HD, Dordunu P (2012) Studies on the physicochemical characteristics, microbial load and storage stability of oil from Indian almond nut (Terminalia catappa L.). Food Sci Qual Manag 8:9-17

47. Souza LTA, Mendes AA, de Castro HF (2016) Selection of lipases for the synthesis of biodiesel from Jatropha oil and the potential of microwave irradiation to enhance the reaction rate. BioMed Res Int. https://doi. org/10.1155/2016/1404567

\section{Submit your manuscript to a SpringerOpen ${ }^{\circ}$ journal and benefit from:}

- Convenient online submission

$\checkmark$ Rigorous peer review

- Open access: articles freely available online

- High visibility within the field

- Retaining the copyright to your article

Submit your next manuscript at $\boldsymbol{\nabla}$ springeropen.com 